\title{
MONITORING CHANGES IN THE MORPHOLOGY AND STORAGE OF A SMALL WATER RESERVOIR: A CASE STUDY FROM VRBOVCE, SLOVAKIA
}

\author{
Roman VÝLETA*1, Peter VALENT ${ }^{1,2}$, Zuzana DANÁČOVÁ ${ }^{3}$
}

\begin{abstract}
One of the most profound problems in the operation of water reservoirs is their siltation by sediments coming from agricultural land. The siltation of water reservoirs can significantly shorten their life spans and prevent them from effectively fulfilling their functions. Therefore, accurate monitoring of the current state and dynamics of siltation processes is critical to maintaining their economic, environmental, and societal functions. This study presents a simple method to evaluate the sedimentation rate of a small water reservoir in Slovakia. The method is based on comparing the results from two bathymetric surveys that were carried out in 2017 and 2019 using an ultrasonic acoustic doppler current profiler (ADCP), which was originally developed to measure river discharges. A raster map of the thickness of the sediment in the reservoir was assembled by subtracting the two bathymetric surveys from each other. The analysis of the results showed that the mean annual sedimentation rate of the reservoir is only $101 \mathrm{~m}^{3} /$ year, representing a mean increment in sediment thickness of $1.4 \mathrm{~cm}$. The method described showed promising results and could be applied to numerous small water reservoirs of a similar size across Slovakia.
\end{abstract}

Address

1 Dept. of Land and Water Resources Management, Faculty of Civil Engineering, Slovak University of Technology in Bratislava, Slovakia.

2 Institute of Hydraulic Engineering and Water Resources Management, Vienna University of Technology, Vienna, Austria

3 Slovak Hydrometeorological Institute, Bratislava, Slovakia

* Corresponding author: roman.vyleta@stuba.sk

\section{Key words}

- $\mathrm{ADCP}$,

- Water reservoir,

- Bathymetry,

- Sedimentation.

\section{INTRODUCTION}

Water reservoirs play an irreplaceable role in water management as the available water sources are characterized by a large degree of variability over time and in space. The available water sources in Slovakia are very often unevenly distributed in terms of their distance to the places where they are needed and in terms of their capacity and the demands of the end-users. Water reservoirs have become a natural part of our landscape, within which they perform a large spectrum of various functions (i.e., flood control, irrigation, water supply, hydropower, recreation). The operation and maintenance of water reservoirs constitute a great challenge, mainly from a technical point of view. One of the main problems with their operation is the reduction of the available storage volume and the shortening of the reservoirs' life-span due to the deposition of sediment (Dutta, 2016; Kondolf et al., 2014; Krasa et al., 2005). The sediments usually come from nearby agricultural land that has become very vulnerable in many parts of Slovakia due to intensive large-scale agriculture and deforestation (Hlavčová et al., 2019; Stankoviansky et al., 2006). Although the sedimentation of water reservoirs cannot be fully eliminated, it is still possible to reduce it by various erosion mitigation measures in their catchments and good agricultural practices on the land near the reservoir. Apart from the reduction of the available storage volume and all the related reservoir functions, the excess sedimentation also 
has a negative impact on the water quality of a reservoir and the biodiversity of aquatic and riparian ecosystems (Annandale, 2005; Verstraeten et al., 2006).

To extend the life-span of reservoirs and preserve their functions with an unchanged degree of efficiency, it is important to monitor the dynamics of their sedimentation. This could be done by carrying out regular bathymetric surveys that could be used to update the information about the reservoirs' storage volume and to identify the thickness of the deposited sediment at different places in the reservoir. Such information is of great value in predicting the future development of the volume of the reservoir, which can be used to propose efficient erosion mitigation measures, update maintenance and operational plans, and adopt strategic decisions by the businesses concerned (e.g., agriculture, hydropower, manufacturing). The literature recognizes several groups of methods for estimating reservoir sedimentation (Carvalho et al., 2000; Morris et al., 1998), including: i) direct measurement and monitoring, ii) remote sensing, iii) empirical and analytical methods, iv) physical modelling, and v) computational modelling. Direct measurements of reservoir beds are among the most accurate methods and are especially useful in cases of small and medium-sized reservoirs. Multiple studies have already been conducted on this topic both worldwide (Ceylan et al., 2011; Merwade, 2009) and in Slovakia (Hlavčová et al., 2018; Honek et al., 2020; Kubinský et al., 2015; Németová et al., 2020; Valent et al., 2019).

This study presents the results of two bathymetric surveys conducted using an acoustic doppler current profiler (ADCP) in 2017 and 2019 in the Vrbovce water reservoir. The surveys were used to estimate the amount of sediments in the reservoir and to create a map of sediment depths identifying areas of erosion and deposition. The estimated intensity of the sedimentation is compared to other studies from the region, and the possible sources for the eroded material as well as the possibilities for its reduction are discussed.

\section{MATERIAL}

\subsection{Study Area}

The area investigated lies in the village of Vrbovce, which is situated in the western part of Slovakia in the foothills of the White Carpathian mountain range near Slovakia's border with the Czech Republic (see Fig. 1). From a climatological point of view, the area of interest belongs to the moderately warm climatic regions with a mean annual air temperature of $7.5{ }^{\circ} \mathrm{C}$ and a mean annual precipitation amount of 650-850 mm. Most of the soil has a clayey-loamy texture and is very susceptible to water erosion. Moreover, the geological structure of the area (flysch) does not provide good conditions for the infiltration of precipitation and surface water into the subsoil. This means that, especially during intensive rainfall events, a large amount of the precipitation is formed into surface runoff with a strong potential to erode, detach and transport soil particles (Stankoviansky, 2003). This is even more pronounced with the expected increase in the occurrence and intensity of extreme precipitation events in the region (Vasilaki et al., 2017) and might further be aggravated if the way the land is used in the reservoir's watershed is changed (Rončák et al., 2017). The fact that the area is poor in groundwater resources but rather rich in agricultural activities has resulted in a large number of small water reservoirs for irrigation being built in the region.

One of such reservoirs is situated in the cadastral area of the village of Vrbovce, which is on the small Zápasečník creek (a leftside tributary of the larger Teplica river). The reservoir was built above the village in 1966 to store water during the wet months and is used to irrigate adjacent agricultural land during drier vegetation periods. Since 1989, the reservoir has only been used for recreational

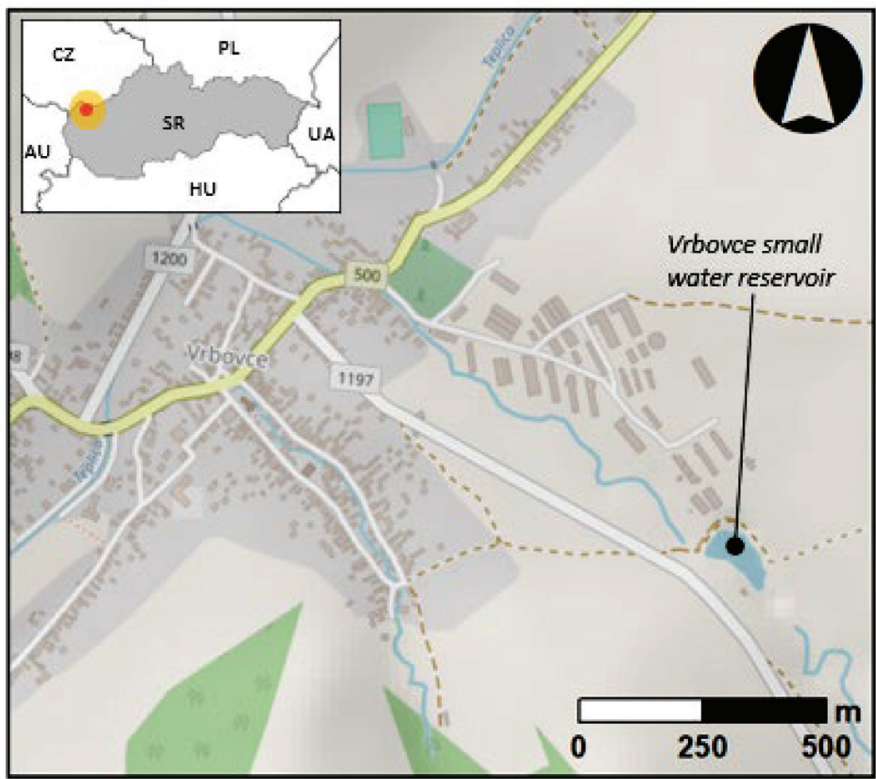

Fig. 1 Location of the small water reservoir

purposes and as a fishing pond for sport fishing. The embankment of the reservoir is a $5.9 \mathrm{~m}$ tall earth dam with a crest of $3 \mathrm{~m}$ in width. The main outlet from the reservoir is a small wooden sluice gate embedded in a bell-mouth emergency spillway. It is used to keep the water in the reservoir at a constant level for most of the year. Under these conditions it covers an area of 0.8 ha (water level $15 \mathrm{~cm}$ bellow the edge of the emergency spillway). The catchment above the reservoir has an area of $3.24 \mathrm{~km}^{2}$ and is mostly covered by meadows and pastures $(56 \%)$, followed by deciduous forests $(25 \%)$, and agricultural land $(17 \%)$, which mainly lie in its upper part. The remaining $2 \%$ of the area is mainly covered by transitional woodland and no urbanized areas.

\subsection{Instruments}

The bathymetric survey of the reservoir was conducted using a multipurpose StreamPro ADCP manufactured by Teledyne RD Instrument. The small size of the reservoir (max. width of only $65 \mathrm{~m}$ ) enabled the use of the instrument, which was primarily designed to measure river discharges. Apart from that, the ADCP also enabled the measurement of the water depths along the measurement path, the current and float velocities, and the surface water temperature. The measuring sensor consists of four transducers that are mounted on a small float. This permits taking measurements of the water depths in a range between $0.1 \mathrm{~m}$ and $7 \mathrm{~m}$ with an accuracy of $1 \%$ (assuming freshwater conditions). The four piezoelectric transducers transmit and receive ultrasonic waves to measure the time needed for the waves to travel from a known point (the transducer's face) to a reflecting surface (the reservoir bed) and back. This, together with the known velocity of sound in water, enables calculating the depth of the water. The ADCP automatically adjusts the velocity of the sound in the water as a function of its temperature, which is measured by a sensor mounted on the face of the transducer. As the maximum depth of the reservoir is rather small $(\sim 4 \mathrm{~m})$ and as its thermal stratification was minimal during the 2017 and 2019 spring month surveys, no further adjustments to the velocity of the sound in the water were considered. The ADCP uses the Bluetooth protocol for wireless communication with the end devices, where the results could be instantaneously displayed and inspected using the manufacturer's WinRiver II software. 
The ADCP used did not come with an embedded GPS sensor. Therefore, its position had to be estimated in a two-step process. As the measurements were taken along fixed transects, their ending points in the first step were precisely measured by an antenna of the Global Navigation Satellite System (GNSS) - Leica GS15 GNSS. During the measurements, the ADCP labelled each measurement with information about the distance from the beginning of the measurement. In the second step, this information was combined with the exact position of the transect's ending points to get the coordinates of each measurement. The GNSS antenna was also used to perform a geodetic survey of the surroundings of the reservoir, including the exact position of the waterline.

\subsection{Bathymetric survey of the small water reservoir and post-processing}

Two bathymetric surveys of the Vrbovce small water reservoir were carried out in 2017 and 2019 using the ADCP described above. The measurements were composed of two stages. In the first stage, the ADCP was used to measure the water depths at multiple locations across the reservoir. In the second stage, the exact elevation of the water level was measured using the GNSS antenna. The elevation of the reservoir bed was calculated by subtracting the water depths from the elevation of the water level. As the ADCP float is not self-propelled, it had to either be towed from one bank of the reservoir to another or mounted on a boat (see Figs. 2b,c). In the 2017 survey, only the first option was used, while in 2019, both options were used.

The first bathymetric survey took place in April 2017. At that time the reservoir was in full operation, so the reservoir bed had to be measured by the ADCP. In 2017, the banks of the reservoir were easily accessible. This allowed for the splitting of the reservoir into 18 equally-spaced transects (see Fig. 3), within which a steel wire rope was stretched from one bank to another to guide the float and to prevent its deviation from the predefined course due to the effect of wind. Subsequently, the float was attached to the guide rope and manually towed to the other bank of the reservoir while taking the measurements. In order to increase the reliability of the survey, two measurements were carried out within each transect.

The second bathymetric survey took place in September 2019. At that time the banks in the upper part of the reservoir were not accessible due to lush riparian vegetation, which did not leave any space for the wire to be stretched from one side to another. Therefore, transects 11 to 18 were not used, and the upper part of the reservoir was measured by towing the ADCP behind a small rubber boat (Fig. 2c). In some places, the shallow water did not allow the boat to get as close to the banks as would have been possible if the transects were used. Nevertheless, the upper part of the reservoir was homogeneously covered with roughly the same distances between the boat paths. The rest of the reservoir was measured at the same transects (1 to 10) as in 2017.

In both surveys, the sampling frequency of the ADCP was set to $0.5 \mathrm{~m}$, since a higher level of detail would not significantly increase the precision of the $3 \mathrm{D}$ model of the reservoir's bed. The points obtained were georeferenced and, by using a simple triangulated irregular network (TIN), the interpolation was converted into a digital elevation model (DEM) with a resolution of $0.5 \mathrm{~m} \times 0.5 \mathrm{~m}$. The reservoir's bed elevation was computed by subtracting the water depths measured from the elevation of the water surface.
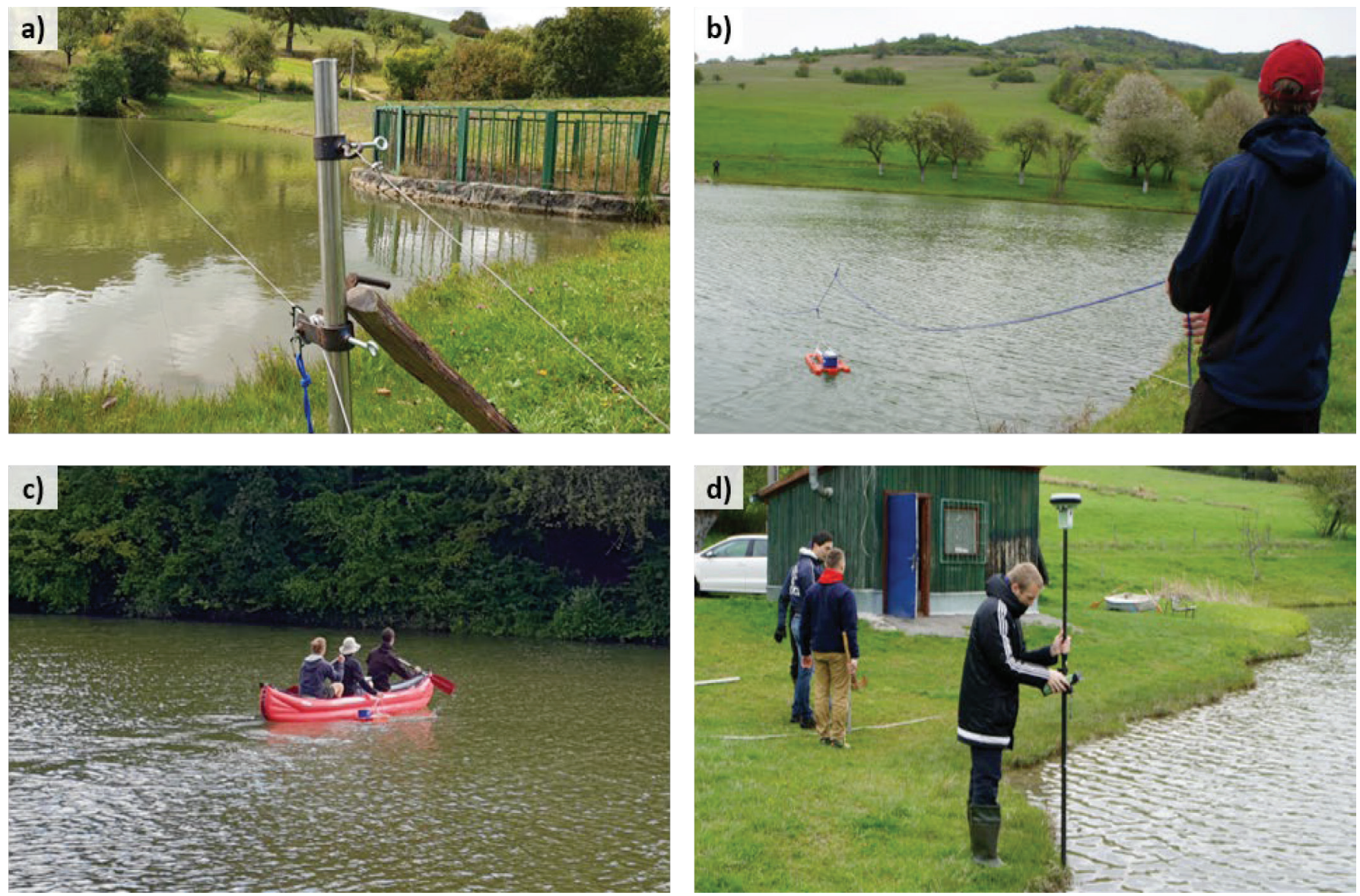

Fig. 2 a) one of the transects with a leading wire rope; $b$ ) manual towing of the ADCP along the transects; $c$ ) towing the ADCP behind a rubber boat; d) geodetic measurement of the waterline position 


\section{RESULTS AND DISCUSSION}

The two bathymetric surveys from 2017 and 2019 were used to estimate the sedimentation rate of the reservoir. The amount of sediments accumulated in the reservoir over a period of 29 months (April 2017 and September 2019) was calculated by subtracting the two DEMs of the reservoir bed's elevation. When subtracting the 2019 bathymetry from the 2017 survey, the result is a $0.5 \mathrm{~m} \times 0.5 \mathrm{~m}$ map of the sediment depths with the positive cells representing areas with sediment deposition and the negative cells representing areas with reservoir bed erosion. The resulting raster map showing the height of the deposited sediments is shown in Fig. 4. It shows that most of the reservoir's bed is subject to sediment deposition as one would expect. The results also show that the sediment deposits are equally distributed over the whole area of the reservoir. The largest sediment deposits could be observed in the upper part of the reservoir just along the path where the Zápasečník river enters the reservoir. This was also expected as the velocity of the river flow drops after it enters the reservoir. The green areas in Fig. 4 represent places where the reservoir bed was eroded. Most of these places are situated along the banks, meaning that some of the sediments do not come from the catchment above the reservoir. The usual causes of bank erosion, i.e., waves and bare banks, are not the case here, which might suggest that the left bank of the reservoir is especially eroded by the current of the Zápasečník river.

By summing the positive and negative cells of the sediment depth raster, information can be obtained on the total volume of the sediments accumulated in the tank. The total volume of the sediments accumulated in the reservoir between the two bathymetric surveys was $246 \mathrm{~m}^{3}(2.8 \mathrm{~cm})$. That volume represents a mean annual sediment increase of $101 \mathrm{~m}^{3} /$ year (29 months), which equals $1.4 \mathrm{~cm} /$ year of sediment depth. It must be noted here that only a small measurement error of $0.5 \mathrm{~cm}$ can mean a difference of $35 \mathrm{~m}^{3}$ in the estimation of the sediment volume. Despite the fact that significant efforts have been exerted to minimize the measurement errors, one does not simply measure the water level elevation with this degree of accuracy, especially when waves are present. Another source of measurement error is associated with the ADCP, which can measure water depths with an accuracy of $1 \%$ under ideal conditions. In the case of the two measurements, when the mean water depth was around $1.96 \mathrm{~m}$, this represents a mean measurement error of almost $\pm 2 \mathrm{~cm}\left(70 \mathrm{~m}^{3}\right)$. In addition, the fact that in 2019, the ADCP could not always follow the same path as in 2017 (neither in the case of the 10 identical transects) brings another source of uncertainty to the estimation of the reservoir's sedimentation rate.

Despite all these sources of uncertainties, the bathymetric survey is very important as it provides information about the current state of the reservoir. The operators and users of the reservoir can identify places where the reservoir banks are severely eroded or where the water depths have decreased due to sediment deposition and then take adequate remedial measures. It is especially important to check the state of the dam of the reservoir and the functionality of the bottom outlet's structure, which should be uncovered and not buried under a layer of the sediments. In this study, the two surveys showed that there was no or little change in the sediment depth under the reservoir's dam. This is important from a maintenance point of view in that the bottom outlet's structure is not the subject of clogging due to increased sediment deposition (see Fig. 4).

The results also showed that the sedimentation rate of the reservoir is rather slow. The main reason for this finding is the way in which the land is used and structured. In 2019, only $17 \%$ of the reservoir's watershed was used for agricultural production. Moreover, most of the agricultural land in the watershed is situated in its upper part and is separated from the river by large patches of forests, shrubs and natural grasslands that can trap a large portion of the eroded material. Several wooden check dams are also dispersed along the catchment to further reduce sediment yields.

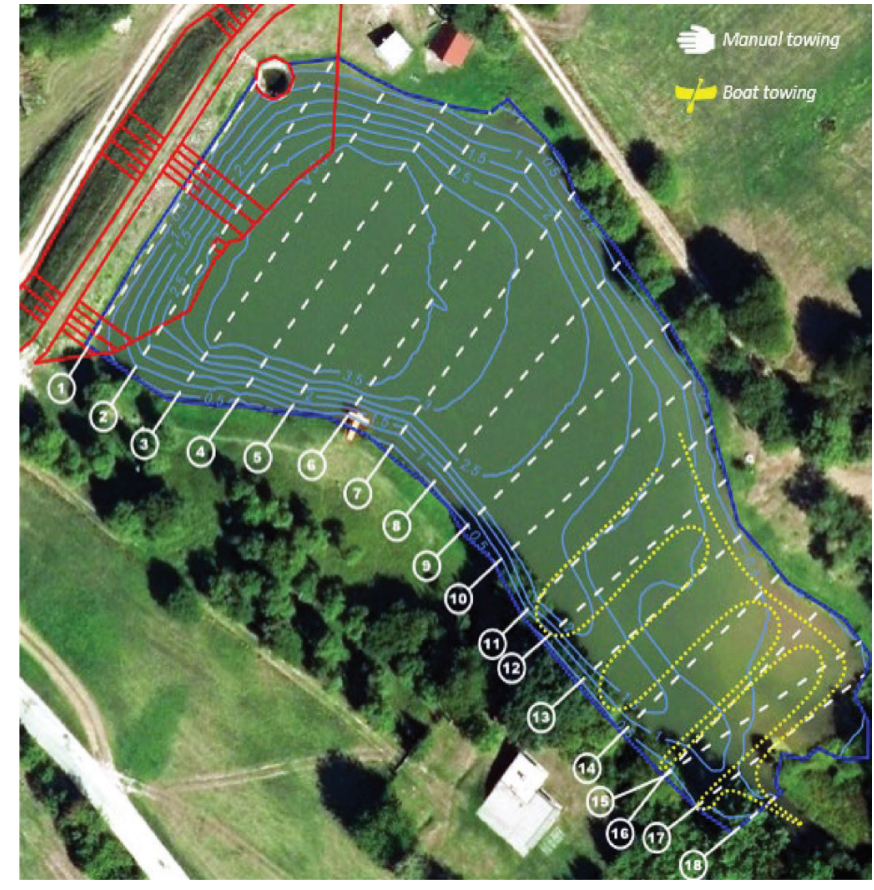

Fig. 3 Water depths from the 2017 bathymetric survey (for a water level at $348.1 \mathrm{~m}$ a.s.l.). (bathymetry 2017 - all 18 transects; bathymetry 2019-transects 1-10 and the path of the boat in yellow)

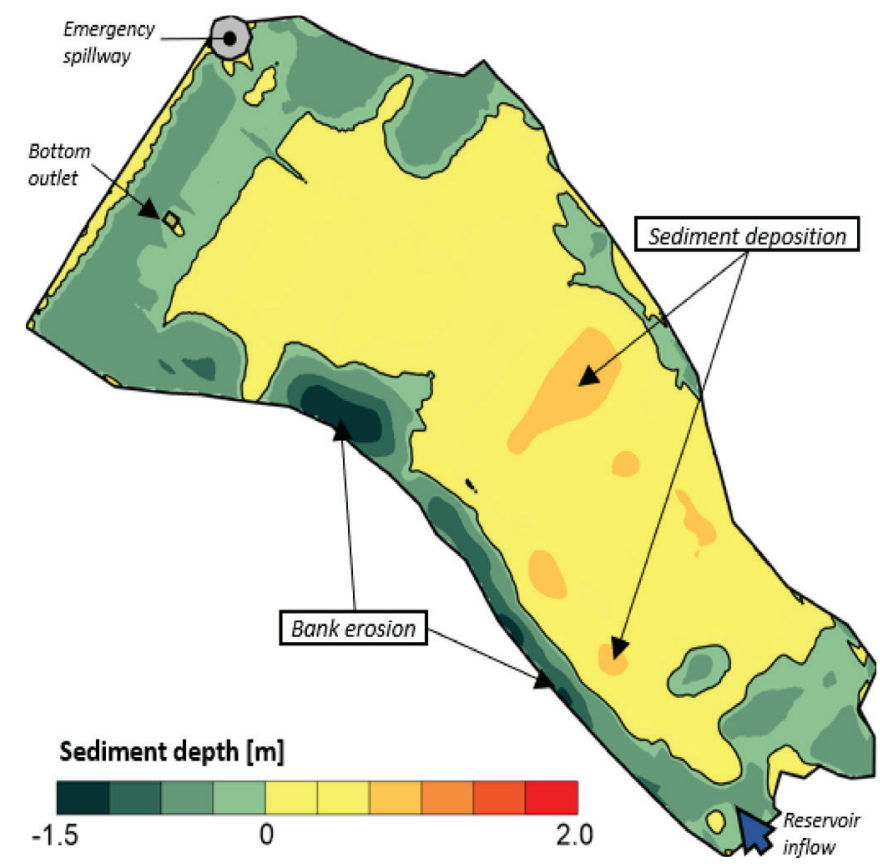

Fig. 4 Sediment depth as estimated from the two bathymetric surveys in 2017 and 2019

In 2008, at the end of extensive maintenance works during which the sediments from the reservoir were excavated by a dry excavation method, a simple geodetic survey of the bottom of the reservoir and the surrounding area was conducted. The amount of sediments that accumulated in the reservoir between 2008 and 2017 was estimated using both monitoring and modelling approaches and published in (Valent et al., 2019). The results obtained exhibited a slow sedimentation rate of the reservoir, which has also been demonstrated in this study. 


\section{CONCLUSIONS}

The sedimentation of water reservoirs is a profound problem that has a direct impact on the life-span of reservoirs and the way in which they serve their primary functions. It is also a natural phenomenon and cannot be fully avoided as some of the sediments transported in a river are deposited in a reservoir due to the decreased velocity of the current and the reduced sediment transport capacity of the water. Moreover, this can also cause serious problems downstream from the reservoir, creating water deprived of sediments with an increased erosive capacity (Kondolf, 1997). Therefore, systematic research of reservoir sedimentation is an important engineering task. Not only does it give information about the current state of the reservoir, it also demonstrates the dynamics of the erosion processes in the watershed. Such information is of great value, especially for reservoir operators, as it allows them to update maintenance plans and operational manuals and to develop predictions concerning the future state of the reservoir.

In this study, the mean annual sedimentation rate of a small water reservoir in the village of Vrbovce was estimated based on the results of two bathymetric surveys. The surveys took place in April 2017 and September 2019 and were carried out using a small ADCP originally designed to measure river discharges. The small size of the reservoir allowed the towing of the ADCP either from one bank to another or behind a small boat. The results indicated a low mean annual sedimentation rate of only $101 \mathrm{~m}^{3} /$ year, which can be mainly attributed to the way the catchment is organized with a forest buffer between the agricultural land and the Zápasečník river. The results also raised a question about the uncertainties associated with the measurements. In order to limit them, it is recommended to always take measurements at the same location and under similar conditions. The methods of the bathymetric survey presented here proved to be accurate, rapid, and economically viable; the survey took only one day to finish with minimum requirements for equipment and staff.

The original function of the water reservoir investigated to provide water for the local agricultural cooperative is no longer relevant. In Slovakia, a number of small water reservoirs that do not serve their original function (usually for irrigation) nowadays lack proper maintenance as their operation is not financially viable (Jurík et al., 2015; Šoltísová, 2014). However, in recent years the increased frequency and duration of droughts have forced businesses to look for new sources of water, which they can find in these unused reservoirs (Szolgay et al., 2005). Their preservation is therefore critical as the current situation in Slovakia favours green measures over the construction of new water reservoirs.

\section{Acknowledgements}

This article was partly created with the support of the Ministry of Education, Science, Research and Sport of the Slovak Republic within the Research and Development Operational Programme for the project "University Science Park of STU Bratislava", ITMS 6240220084, co-funded by the European Regional Development Fund. This research was partially funded by the Slovak Research and Development Agency, Grant No. APVV-15-0497 and by the Slovak Science Grant Agency, Grant No. VEGA 1/0632/19. The authors are grateful for their support. 


\section{REFERENCES}

Annandale, G.W. (2005) Reservoir Sedimentation, In: Anderson, M. G. (ed.) Encyclopedia of Hydrological Sciences, Chichester: John Wiley and Sons, pp. 1327-1339. ISBN: 0-471-49103-9

Carvalho, N. de O. - Filizola, N.P. - Santos, P.M.C. - Lima, J.E.F.W. (2000) Reservation Sedimentation Assessment Guideline, Brasil: ANEEL - Brazilian Electricity Regulatory Agency.

Ceylan, A. - Karabork, H. - Ekizoglu, I. (2011) An analysis of bathymetric changes in Altinapa reservoir, Carpathian Journal of Earth and Environmental Sciences, 6, 2, pp. 15-24.

Dutta, S. (2016) Soil erosion, sediment yield and sedimentation of reservoir: a review, Modeling Earth Systems and Environment, 2, 3, p. 123. DOI: 10.1007/s40808-016-0182-y

Hlavčová, K. - Danáčová, M. - Kohnová, S. - Szolgay, J. - Valent, P. - Výleta, R. (2019) Estimating the effectiveness of crop management on reducing flood risk and sediment transport on hilly agricultural land - A Myjava case study, Slovakia, CATENA, 172, pp. 678-690. DOI: 10.1016/J.CATENA.2018.09.027

Hlavčová, K. - Kohnová, S. - Velísková, Y. - Studvová, Z. - Sočuvka, V. - Ivan, P. (2018) Comparison of two concepts for assessment of sediment transport in small agricultural catchments, Journal of Hydrology and Hydromechanics, 66, 4, pp. 404-415. DOI: $10.2478 /$ johh-2018-0032

Honek, D. - Michalková, M.Š. - Smetanová, A. - Sočuvka, V. Velísková, Y. - Karásek, P. - Konečná, J. - Németová, Z. Danáčová, M. (2020) Estimating sedimentation rates in small reservoirs - Suitable approaches for local municipalities in central Europe, Journal of Environmental Management, 261, p. 109958. DOI: 10.1016/j.jenvman.2019.109958

Jurík, L. - Húska, D. - Sedmáková, M. (2015) Malé vodné nádrže v $S R$ - ohrozený zdroj vody pre závlahy? [Small water reservoirs in Slovakia - threatened source of water for irrigation?], Závlahy a jejich perspektiva, Mikulov, March 18-19, pp. 1-12. ISBN: 97880-87577-47-9 (in Slovak)

Kondolf, G.M. (1997) Hungry Water: Effects of Dams and Gravel Mining on River Channels, Environmental Management, 21, 4, pp. 533-551. DOI: $10.1007 / \mathrm{s} 002679900048$

Kondolf, G.M. - Gao, Y. - Annandale, G.W. - Morris, G.L. - Jiang, E. - Zhang, J. - Cao, Y. - Carling, P. - Fu, K. - Guo, Q. - Hotchkiss, R. - Peteuil, C. - Sumi, T. - Wang, H.-W. - Wang, Z. - Wei, Z. - Wu, B. - Wu, C. - Yang, C.T. (2014) Sustainable sediment management in reservoirs and regulated rivers: Experiences from five continents, Earth's Future, 2, 5, pp. 256-280. DOI: $10.1002 / 2013 E F 000184$

Krasa, J. - Dostal, T. - Van Rompaey, A. - Vaska, J. - Vrana, K. (2005) Reservoirs' siltation measurements and sediment transport assessment in the Czech Republic, the Vrchlice catchment study, CATENA, 64, 2, pp. 348-362. DOI: 10.1016/j.catena.2005.08.015

Kubinský, D. - Weis, K. - Fuska, J. - Lehotský, M. - Petrovič, F. (2015) Changes in retention characteristics of 9 historical artificial water reservoirs near Banská Štiavnica, Slovakia, DOI: 10.1515/geo-2015-0056
Merwade, V. (2009) Effect of spatial trends on interpolation of river bathymetry, Journal of Hydrology, 371, 1, pp. 169-181. DOI: 10.1016/j.jhydrol.2009.03.026

Morris, G.L. - Fan, J. (1998) Reservoir Sedimentation Handbook: Design and Management of Dams, Reservoirs, and Watersheds for Sustainable Use, McGraw Hill Professional, 866 pp. ISBN: 978-0-07-043302-1

Németová, Z. - Honek, D. - Kohnová, S. - Hlavčová, K. - Šulc Michalková, M. - Sočuvka, V. - Velísková, Y. (2020) Validation of the EROSION-3D Model through Measured Bathymetric Sediments, Water, 12, 4, p. 1082. DOI: 10.3390/w12041082

Rončák, P. - Lisovszki, E. - Szolgay, J. - Hlavčová, K. - Kohnová, S. - Csoma, R. - Poórová, J. (2017) The potential for land use change to reduce flood risk in mid-sized catchments in the Myjava region of Slovakia, Contributions to Geophysics and Geodesy, 47, 2, pp. 95-112. DOI: 10.1515/congeo-2017-0007

Šoltísová, A. (2014) Stav malých vodných nádrži v povodí rieky Bodrog [State of small water reservoirs in the river basin Bodrog], XXXIV. Priehradné dni 2014, Slovenský vodohospodársky podnik, Horný Smokovec, June 24-26, pp. 1-7. ISBN: 978-80971596-6-5 (in Slovak)

Stankoviansky, M. (2003) Historical evolution of permanent gullies in the Myjava Hill Land, Slovakia, CATENA, 51, 3, pp. 223-239. DOI: $10.1016 / \mathrm{S} 0341-8162(02) 00167-4$

Stankoviansky, M. - Fulajtár, E. - Jambor, P. (2006) Slovakia, In: Boardman, J. - Poesen, J. (eds.) Soil Erosion in Europe, John Wiley \& Sons, Ltd, pp. 117-138. DOI: 10.1002/0470859202. ch11 ISBN: 978-0-470-85920-9

Szolgay, J. - Hlavčová, K. - Kohnová, S. - Čistý, M. - Danáčová, M. - Valent, P. - Výleta, R. (2005) Analýza a zhodnotenie hydrologickej bilancie na toku Parná a vodohospodárskej sústavy nádrže Horné Orešany [Analysis and evaluation of the hydrological balance on the Parná river and the water management system of the Horné Orešany reservoir], Bratislava: Slovenská technická univerzita v Bratislave. pp. 68. (in Slovak)

Valent, P. - Výleta, R. - Danáčová, M. (2019) A Joint Sedimentation-Flood Retention Assessment of a Small Water Reservoir in Slovakia: A New Hope for Old Reservoirs?, Geosciences, 9, 4, p. 158. DOI: $10.3390 /$ geosciences 9040158

Vasilaki, M. - Kohnová, S. - Hanel, M. - Szolgay, J. - Hlavčová, K. - Loukas, A. - Rončák, P. (2017) Detection of future changes in seasonality in extreme short-term rainfall in selected stations of Slovakia, Contributions to Geophysics and Geodesy, 47, 2, pp. 133-148. DOI: 10.1515/congeo-2017-0009

Verstraeten, G. - Bazzoffi, P. - Lajczak, A. - Rãdoane, M. - Rey, F. - Poesen, J. - Vente, J. de (2006) Reservoir and Pond Sedimentation in Europe, In: Boardman, J. - Poesen, J. (eds.) Soil Erosion in Europe, John Wiley \& Sons, Ltd, pp. 757-774. DOI: 10.1002/0470859202.ch54 ISBN: 978-0-470-85920-9 